\title{
Vaccination in Nile tilapia broodstock with whole cell vaccine and disease resistance in its fry against Aeromonas hydrophila
}

\author{
Vaksinasi induk ikan nila dengan vaksin sel utuh dan ketahanan benih yang \\ dihasilkannya terhadap Aeromonas hydrophila
}

\section{Sukenda Sukenda*, Odang Carman, Rahman Rahman, Dendi Hidayatullah, Nurfitriani Siti Yumaidawati}

\author{
Department of Aquaculture, Faculty of Fisheries and Marine Science, Bogor Agricultural University \\ Campus IPB Dramaga Bogor, West Java, Indonesia 16680 \\ *E-mail: sukenda67@gmail.com
}

\begin{abstract}
The aim of this study was to analyze the effectivity of vaccination in Nile tilapia broodstock with whole cell vaccine and disease resistance in fry tilapia against Aeromonas hydrophila. Tilapia Nirwana strain that used for this had average body weight of $185 \pm 13.23 \mathrm{~g}$ and were maintained in ponds sizing of $\left(2.5 \times 2.5 \times 1 \mathrm{~m}^{3}\right)$. Vaccinations that has been done through intraperitoneal injection using dose of $0.1 \mathrm{~mL} / \mathrm{fish}$, meanwhile the fish for control was injected by phosphate buffered saline (PBS). This study used complete randomized design with two treatments and three replications. Antibody level was measured by using indirect enzyme-linked immunosorbent assay (ELISA) method in the broodstock, egg, and fry. Challenge test in fry tilapia performed at the age of 5, 10, and 15 days. The results showed that vaccination in tilapia broodstock delivered a significant antibody level in broodstock, eggs, and fry $(\mathrm{P}<0.05)$ compared to the control. Relative percent survival of offspring at 5, 10, and 15 days were $78.26 \%, 70.59 \%$, and $65.52 \%$, respectively. As a conclusion, vaccination in tilapia broodstock was effective to improve specific and non-specific immunity, and protect fry tilapia from A. hydrophila infection through maternal immunity.
\end{abstract}

Keywords: vaccination, antibody, maternal immunity, tilapia, Aeromonas hydrophila

\begin{abstract}
ABSTRAK
Penelitian ini bertujuan untuk menganalisis efikasi vaksinasi pada induk nila dengan vaksin sel utuh dan ketahanan benih yang dihasilkan terhadap Aeromonas hydrophila. Ikan nila stain Nirwana yang digunakan dalam penelitian memiliki bobot rata-rata $185 \pm 13,23 \mathrm{~g}$ dan ikan dipelihara dalam kolam $\left(2,5 \times 2,5 \times 1 \mathrm{~m}^{3}\right)$. vaksinasi dilakukan melalui penyuntikan intraperitoneal dengan dosis $0,1 \mathrm{~mL} / \mathrm{ikan}$, sementara itu ikan kontrol disuntik dengan phosphate buffered saline (PBS). Penelitian ini menggunakan rancangan acak lengkap dengan dua perlakuan dan tiga ulangan. Tingkat antibodi diukur dengan menggunakan metode indirect enzyme-linked immunosorbent assay (ELISA) pada induk, telur dan benih. Uji tantang pada benih dilakukan pada umur 5, 10, dan 15 hari. Hasil penelitian menunjukan bahwa vaksinasi pada induk nila secara signifikan dapat meningkatkan level antibodi pada induk, telur, dan benih $(\mathrm{P}<0,05)$ dibandingkan dengan kontrol. Kelangsungan hidup relatif pada benih berumur 5 , 10, dan 15 hari masing-masing adalah 78,26\%; 70,59\%; dan 65,52\%. Sebagai kesimpulan vaksinasi pada induk nila efektif dalam memperbaiki imunitas spesifik dan non spesifik serta melindungi benih dari infeksi A. hydrophila melalui imunitas maternal.
\end{abstract}

Kata kunci: vaksinasi, antibodi, imunitas maternal, ikan nila, Aeromonas hydrophila

\section{INTRODUCTION}

Tilapia Oreochromis niloticus is one of the famous fresh water fish commodity in Indonesia. KKP (2016) stated that total production of tilapia in 2014 to 2015 was increased. Total production of tilapia in 2014 was 999,695 tons and increased significantly in 2015 to $1,576,607$ tons or vice versa, it increased to average of $30.29 \%$. Intensive tilapia fish farming at this time still face obstacles. One of the obstacle that faced was motile aeromonads septicemia (MAS) 
disease caused by Aeromonas hydrophila bacteria infection (Tantu et al., 2013; Hardi et al., 2014). Clinical symptoms of infected fish were hemorrhagic, wound, ulcer, severe scale and fin, and blackened skin (Hardi et al., 2014).

Fry stage in fish is the most critical stage because fry fish has not been able to improve their immune response yet, so the mortality rate against disease in this stage is high enough (Mingming $e t$ $a l ., 2014)$. The conditions on fry stage still rely on transferred immunity by its mother (Wang et al., 2009). Health status of broodstock fish will affect the fry fish (Swain \& Nayak, 2009). Therefore, the procurement of the healthy broodstock fish is a must in order to produce the best quality of fry fish.

One of the effort to improve the health of broodstock tilapia as a prevention effort to handle MAS disease in fry tilapia is through maternal immunity engineering, like fish broodstock vaccination (Wang et al., 2012; Mingming et al., 2014; Nisaa et al., 2016; Sukenda et al., 2017). Transferred maternal immunity engineering with broodstock vaccination is an alternative way to increase the immunity of fish larvae and anticipate the increasing of fry fish mortality rate (Wang et al., 2009; Zhang et al., 2013). Broodstock vaccination using whole cell bacteria can reduce the mortality rate of fry fish. The previous study on some fish species showed that antibody and lysozyme of broodstock will be transferred to its fry and give the best protection against bacteria.

The study aimed to review the succesful maternal immunity transfer in the form of antibody and lysozyme from broodstock fish that has been vaccinated with the whole cell of A. hydrophila and the resistance level of fry fish after the challenge test.

\section{MATERIALS AND METHODS}

\section{Preparation of broodstock ponds}

The used ponds for broodstock fish rearing was three concrete ponds sizing of $2.5 \times 2.5 \times 1 \mathrm{~m}^{3}$. First, the ponds cleaned from dirt and moss that stuck to its edge. The ponds washed and dried for 24 hours. After 24 hours, then the ponds filled with water and added aeration for each ponds was two pieces, and the ponds was ready to use as broodstock rearing container.

\section{The broodstock procurement and maintainance}

The broodstock procurement is done by weighing, measuring of body length, and checking maturity level of broodstock's gonad. The level of gonad maturity can be known by using catheter or cannulation by taking the egg sac in fish eggs. As many as 150 of female tilapia were sorted and obtained as much as nine healthy female broodstock. The broodstock of tilapia used for this study came from Wanayasa Freshwater Fish Seed Development Center, West Java. The amount of female broodstock tilapia that stocked for each treatment was three fishes with average weights of $185 \pm 13.2 \mathrm{~g}$ and the average length of $20 \pm 0.3 \mathrm{~cm}$. Wereas the male broodstock tilapia that stocked for each treatment was only fish with average weights of $230 \pm 18.3$ $\mathrm{g}$ and length of $24 \pm 1.1 \mathrm{~cm}$. The spawning ratio of male and female broodstock tilapia was 1:3. The broodstock then maintained and fed with $40 \%$ protein content. Feeding occurs at satiation with frequency twice a day, in the morning at $08.00 \mathrm{am}$ and an afternoon at $16.00 \mathrm{pm}$.

\section{Characterization of bacteria and enhancement of virulence}

Bacterial isolates came from the collections of the laboratory of aquatic organism health, Department of Aquaculture, Bogor Agricultural University. The isolates of bacteria cultured in brain heart infusion agar (BHIA) medium then cultured continue in brain heart infusion broth (BHIB) medium for 24 hours then injected to fish in order to enhance the virulence. Enhancement of virulence is done by injecting a liquid culture of $A$. hydrophila bacteria that have been washed with phosphate buffer saline (PBS) as much as $0.1 \mathrm{~mL}$ into intramuscular fish. After the symptoms like ulcers and hemorrhagic appeared, the bacteria was reisolated to BHIA medium from kidney of infected fish and incubated for 24 hours at a temperature of $29^{\circ} \mathrm{C}$ to $30^{\circ} \mathrm{C}$. The result from reisolated bacteria was purified into four quadrants in a plate and recharacterized. Characterization of bacteria conducted in this study using the API 20E KIT. The results of the characterization using the API 20E KIT showed that the bacteria was Aeromonas hydrophila with the similarity level of $94 \%$.

\section{The production of vaccine}

The production of whole cell vaccine of $A$. hydrophila refers to Sugiani et al. (2012). The pure cultured of $A$. hydrophila bacteria removed by picking a single colony from original culture tube to BHIB liquid medium as much as $50 \mathrm{~mL}$ and incubated in a water shaker in a speed of 140 
rpm for 24 hours in $29^{\circ} \mathrm{C}$ to $30^{\circ} \mathrm{C}$. After that, the total amount of bacteria was counted by using total plate count (TPC) method. The results of cultured bacteria $\left(10^{9} \mathrm{CFU} / \mathrm{mL}\right)$ added with $38 \%$ of neutral buffered formalin (NBF) as much as $3 \%$ from total volume and reincubated for 24 hours to activate the bacteria. The results of the proliferation of bacteria candidate that have been incubated then should be centrifuged with speed of $5000 \mathrm{rpm}$ for 30 minutes to separate its supernatants and pellets. Supernatant disposed of, whereas the pellets washed with phosphate buffer saline (PBS) twice. After that, the vaccine soluble with PBS to its initial volume. The produced vaccine tested its viability by scraping the bacteria vaccine candidate in BHIA medium and incubated for 24 hours. If the bacteria did not grow, the vaccine is actually safe to use.

\section{Vaccination and broodstock breeding}

Tilapia broodstock that will be vaccinated was observed the maturity level of its gonad first by using catheter/cannulation. Broodstock vaccination performed on the level two of maturity phase (TKG II) (Nisaa et al., 2017). Vaccination performed in a healthy female tilapia broodstock and not attacked by a disease. Then female broodstock vaccinated through intraperitoneal (the IP) injection as much as 0.1 $\mathrm{mL}$ of each. Female broodstock that has been vaccinated, gave a tag to distinguish between every treatment. Then it returned to a ponds of spawning together with male tilapia broodstock. The spawning is done naturally during two to three week after vaccination.

\section{Hatching eggs and broodstocks fish farming}

The container that used for hatching eggs and fry fish farming was an aquarium sizing of $60 \times 30 \times 25 \mathrm{~cm}^{3}$. Tilapia eggs produced as many as 1250 eggs. After that, eggs were incubated in a floating sieve (net filters) in an aquarium until they hatch. Hatching container equipped with an aeration system. After hatching and the egg yolk supplies ran out, fry tilapia fed with natural feed tubificid worms in ad libitum. Water quality of fry fish farming maintained in a temperature range of $28-30{ }^{\circ} \mathrm{C}, \mathrm{pH}$ value $6.57-7.89$, dissolved oxygen (DO) $5.2-7.6 \mathrm{mg} /$ $\mathrm{mL}$, and ammonia $0.00080 .0006 \mathrm{mg} / \mathrm{mL}$.

\section{The challenge test for fry fish}

The fry tilapia fish that used for challenge test was at the age of 5, 10, and 15 days. Challenge test in fry fish is done through immersion. Bacterial concentration used for the test challenge based on the results of the LC50 i.e. $10^{7} \mathrm{CFU} / \mathrm{mL}$. The used container was a jar that has a diameter of $15 \mathrm{~cm}$ and filled with water as much as $1 \mathrm{~L}$. The fry was taken as many as 20 fishes and soaked with the suspension of bacteria for an hour. After that, the fry restored in fry fish farming media and the mortality rate observed for 7 days.

\section{The preparation of serum sampel of broodstock fish, homogenous egg and fry fish}

The broodstock and fry of tilapia fish fainted by using ocean free special arowana tabilizer anesthetic with a dose of $1 \mathrm{~mL}$ per $3 \mathrm{~L}$ of water. A blood sample from the broodstock is taken through the vein vessels of tail rot. Blood serum sample preparation refers to Hanif et al. (2004). The blood stored in a room temperature for one to two hours and then stored for 24 hours at a temperature of $4{ }^{\circ} \mathrm{C}$. Serum was collected by centrifuging it at $5000 \mathrm{rpm}$ for 10 minutes, transferred into microtube and the serum was stored at a temperature of $-20^{\circ} \mathrm{C}$ for antibody and lysozyme level testing. Eggs were collected directly after the broodstock spawns. The fry fish was taken at 5, 10, and 15 days after hatching. Collected eggs and fry fishes homogenized in PBS-T (PBS 0.05\% Tween-20) solution with ratio $1: 4$. Next, it centrifuged at $5000 \mathrm{rpm}$ for 10 minutes at a temperature of $4{ }^{\circ} \mathrm{C}$. Supernatant (its homogeneity) then separated into the microtube and stored it at a temperature of -20 ${ }^{\circ} \mathrm{C}$ for antibody and lysozyme level testing

\section{Parameters of observation}

The observed parameters in this study include broodstock hematology (total leukocyte, erythrocytes, haemoglobin, phagocytic activity, and hematocrit levels), the lysozyme activity of the broodstock, egg, and fry), the antibody level (broodstock, egg, and fry), the mortality, and relative percent survival of fry. Broodstock sampling performed two weeks after vaccination, eggs sampling performed directly after the broodstock spawns, and fry sampling performed at the age of 5, 10, and 15 days after hatching.

\section{Total erythrocytes in broodstock}

Blood suction used red pipe as much as 0.5. Then, it diluted with a solution of Hayem's up to the scale of 101. After that it homogenized by hand forming patterns figures of eight for 3 to 5 minutes. Furthermore, the first blood 
droplet was dumped then the next drop shed to haemocytometer, and then observed under the microscope and counted the number of erythrocytes. The formula to calculate the total erythrocytes is as follows:

\section{EErythrocytes $\left(\right.$ cell $\left./ \mathrm{mm}^{3}\right)=$ $\underline{\text { counted cell } \times \text { dilution factor }}$} box volume

\section{Total leukocytes in broodstock}

Blood suction used white pipe as much as 0.5 . Then, it diluted with a solution of Turk's up to the scale of 11 . After that it homogenized by hand forming patterns figures of eight for 3 to 5 minutes. Furthermore, the first blood droplet was dumped then the next drop shed to haemocytometer, and then observed under the microscope and counted the number of leukocytes. The formula to calculate the total leukocytes is as follows:

$$
\begin{aligned}
& \begin{array}{l}
\text { Lleukocytes }\left(\mathrm{cell} / \mathrm{mm}^{3}\right)= \\
\text { counted cell } \times \text { dilution factor }
\end{array} \\
& \text { box volume }
\end{aligned}
$$

\section{Haemoglobin level in broodstock}

Blood suction used sahli pipette as much as $20 \mathrm{~mm}^{3}$ and is inserted into the tube of haemometer that has already filled with $0.1 \mathrm{~N}$ $\mathrm{HCl}$ up to scale 10 . Then it stirred and waited up to 2 to 3 minutes. After that, the aquades added until the color change to standard color contained in $\mathrm{Hb}$ meters. Then the result is read by looking at the yellow scale on the $\mathrm{Hb}$ tube.

\section{Hematocrit level in broodstock}

The blood is inserted into the capillary pipe or hematocrit tube as much as $3 / 4$ part of it. Then closed it with crystoceal. Next, it centrifuged at $5000 \mathrm{rpm}$ for 5 minutes. And then, the number of formed sediment was calculated. A formula to calculate the levels of hematocrit as follows:

$$
\text { Hc }(\%)=\frac{\text { blood precipitation length }}{\text { total blood length }} \times 100
$$

\section{Phagocytic activity in broodstock}

Staphylococcus aureus bacteria was cultured in triptic soy broth (TSB) medium for 18 hours. $10^{7} \mathrm{CFU} / \mathrm{mL}$ of bacteria and fish blood was taken of each as much as $50 \mu \mathrm{L}$, mixed it, and incubated it in room temperature for 20 minutes. After that, the blood drop shed into slide, then withdrawn it by another slide forming an angle of $45^{\circ}$ and drained it. Next, the slide soaked with methanol for 10 minutes and drained. Then slide soaked with Giemsa solution for 10 minutes and rinsed it by using aquades and then drained it again. Furthermore, it observed under the microscope. The formula to calculate the phagocytic activity as follows:

Phagocytic activity $(\%)=$

$\sum$ Phagocytizing cell / $\sum$ Phagocytic cell $\times 100$

Lysozime activity of broodstock, eggs, and fry fish

The bacteria Micrococcus lysodeikticus $(0.4$ $\mathrm{mg} / \mathrm{mL}$ in $0.1 \mathrm{M}$ phosphate buffered saline, $\mathrm{pH}$ 6.2 at $25^{\circ} \mathrm{C}$ ). Blood serum put in as many as $100 \mu \mathrm{L}$ into a microplate. Then the bacteria $M$. lysodeikticus put into microplate that containing the sample as much as $100 \mu \mathrm{L}$. The microplate has contained with the serum and bacteria, put in a microplate reader (Kayto RT-2100C) for reading its absorbance with the wavelength of 450 $\mathrm{nm}$ for 30 seconds up to 60 minutes of mixing. The activity of lysozyme is measured based on a decrease in optical density (OD) of $0.001 /$ minute. The activity of lysozyme is formulated as follows:

Lysozyme activity $($ Unit $/ \mathrm{mL})=$

(initial OD - final OD) $\times 1000$

time of final measurement

volume of samples

Antibody level of broodstock, eggs, and fry fish

ELISA test for measuring antibody levels is done by referring to Sumiati et al. ( 2015). Microtiter plate coated with antigens that obtained from the results of bacteria sonification in the frequency of $40 \mathrm{~Hz}$ for 5 minutes with the optimization antigens of $10 \mu \mathrm{g} / \mathrm{mL}$, and then incubated at a temperature of $4{ }^{\circ} \mathrm{C}$ for 24 hours (overnight). Microtiter washed using PBS-T (PBS, pH $7.40 .05 \%$ Tween-20). It added with $100 \mu \mathrm{L}$ bovine serum albumin (BSA, Sigma) 3\% $\mathrm{w} / \mathrm{v}$ in $\mathrm{H}_{2} \mathrm{O}$, stored it at temperature of $25^{\circ} \mathrm{C}$ for 1 hour, then the plate washed with PBS-T. The sample diluted in PBS-T 1:100, added into 100 $\mu \mathrm{L}$ microtiter with three replications. The plate incubated at $25{ }^{\circ} \mathrm{C}$ for 1 hour then washed it with PBS-T. Ig anti-tilapia long chain for specific polyclonal antibodies diluted to ratio 1:200 in PBS-T and added $100 \mu \mathrm{L}$ to each of microtiter. Plate incubated at a temperature of $25{ }^{\circ} \mathrm{C}$ for 1 hour then washed using PBS-T. It added with peroxidase-conjugated rabbit anti rabbit (Sigma) 
that diluted to ratio 1:10,000 in PBS-T and it added $100 \mu \mathrm{L}$ to each of microtiter. Plate incubated at a temperature of $25^{\circ} \mathrm{C}$ for 1 hour then washed. It added with $100 \mu \mathrm{L}$ to each of microtiter One Step Ultra-TMB-Elisha (Sigma) (TMB $5 \mathrm{mg} 10 \mu \mathrm{L}$ $38 \% \mathrm{H}_{2} \mathrm{O}_{2}$ in $5 \mathrm{~mL}$ of acetate buffer $\mathrm{pH} 5$ ). After 20 minutes, the reaction of ELISA then stopped by adding $50 \mu \mathrm{L}$ of $3 \mathrm{M} \mathrm{H}_{2} \mathrm{SO} 4$ into each of microplates. The reading the optical density (OD) is then done using a Microplate Reader (Kayto RT-2100C) at a wavelength of $450 \mathrm{~nm}$.

\section{Mortality rate of fry}

Mortality of fry was determined at the age of 5,10 , and 15 days after hatching post challenge test with A. hydrophila and calculated using the following formula:

$$
\mathrm{MR}=\mathrm{Mt} / \mathrm{Mo} \times 100
$$

Note:

MR = mortality $(\%)$

Mt $=$ the number of the dead fish at the final observation (individuals)

Mo $=$ the number of the dead fish at the initial observation (individuals)

\section{Relative percent survival (RPS) of fry}

The relative percent survival was determine on the fry produced by vaccinated broodstock. RPS was calculated at the fry age of 5, 10, and 15 days after hatching using the following formula:

$$
\begin{array}{ll} 
& \operatorname{RPS}=[1-(\mathrm{Mv} / \mathrm{Mc})] \times 100 \\
\text { Note: } & \\
\mathrm{RPS}=\text { relative percent survival }(\%) \\
\mathrm{Mv}=\text { mortality of treatment }(\%) \\
\mathrm{Mc}=\text { mortality of control }(\%)
\end{array}
$$

\section{Data analysis}

The data of broodstock hematology, lysozyme activity and antibody level (broodstock fish, eggs, and fry fish), and the mortality rate (MR) test analysis used independent samples t-test with a 95\% interval of confidence by using SPSS 23.0. The data of relative percent survival (RPS) of fry was analyzed descriptively.

\section{RESULTS AND DISCUSSIONS}

\section{Results}

Observation of broodstock hematology

The observations of hematology that presented in Table 1 showed the total value of erythrocytes, hemoglobin level, and hematocrit level did not significantly differ $(\mathrm{P}>0.05)$ between treatments. While the total value of leukocytes, phagocytic activity, lysozyme activity, and antibody level showed significantly different results $(\mathrm{P}<0.05)$ between treatments. The average total value of leukocytes obtained from $1.20-1.65 \times 10^{5}$ cells/ $\mathrm{mm}^{3}$, the average of phagocytic activity was $22.46-38.65 \%$. The average of lysozyme activity obtained of $19.50-43.33$ units $/ \mathrm{mL}$ whereas the average of antibody levels was OD: 0.57-0.79.

\section{Lysozyme activity of eggs and fry fish}

The Data on lysozyme activity of eggs and dry fish that presented in Table 2 showed the significantly different result $(\mathrm{P}<0.05)$ between treatments. The average value of lysozyme activity of eggs was $19.72-33.11$ units $/ \mathrm{mL}$. The average value of lysozyme activity of fry fish at the age of 5 and 6 days had the same value, it was $12.66-20.88$ units $/ \mathrm{mL}$ and lower than the lysozyme activity of fry fish at the age of 15 days with a value of $2.44-24.89$ units $/ \mathrm{mL}$.

\section{Antibody level of eggs and fry fish}

The value of antibody level in eggs and fry fish that presented in Table 3 showed the significantly different result $(\mathrm{P}<0.05)$ between treatments. The value of the antibody level in eggs that came from broodstock control and vaccinated broodstock was of OD: 0.28 to 0.58 . The value of antibody level of fry fish at the age of 5 days was larger, it was OD: 0.56, compared fry fish at the age of 10 days was OD: 0.46 and 15 days was OD: 0.42 .

\section{Mortality rate and relative percent survival (RPS) of fry tilapia fish after challenge test}

Observation results on the mortality rate of fry tilapia fish after a challenge test showed significantly different relative $(\mathrm{P}<0.05)$ between treatments. It can be seen that the mortality rate after challenge test in fry fish at the age of 5 days obtained that the control was $76.67 \%$ and the vaccine treatment was $16.67 \%$ with $78.26 \%$ of relative percent survival. After challenge test, the results of fry fish at the age of 10 days showed the control was $56.67 \%$ and the vaccine treatment was $16.67 \%$ with a relative percent survival of $70.59 \%$. After challenge test, the results of fry fish at the age of 15 days showed the control was $48.33 \%$ and the vaccine treatment was $16.67 \%$ with $65.52 \%$ of relative percent survival. Mortality rates and relative percent survival results of fry tilapia fish after challenge test presented in Table 4. 


\section{Discussion}

Motile aeromonads septicemia (MAS) is one of the diseases that attack tilapia fish (Fernandez et al., 2014). The disease caused by the bacteria $A$. hydrophila. This bacteria is a Gram-negative and live with normal flora in freshwater (Dehghani et al., 2012). A. hydrophila is non-specific bacteria living in a host, so it can attack all the species of freshwater fish. The impact caused this bacteria is hemorrhagic and end to death (Fu et al., 2014). Fish vaccination is one of the prevention efforts that can be done to solve the problem of this disease by means of inducing the specific immune (Gudding et al., 2013; Yi et al., 2014).

Tabel 1. Hematology and antibody level of broodstock as a control and vaccinated

\begin{tabular}{lcc}
\hline Parameters & Control & Vaccinated \\
\hline Erythrocytes $\left(\times 10^{6}\right.$ cells $\left./ \mathrm{mm}^{3}\right)$ & $1.20 \pm 0.09 \mathrm{a}$ & $1.11 \pm 0.09 \mathrm{a}$ \\
Hemoglobin $(\mathrm{g} \%)$ & $6.33 \pm 0.42 \mathrm{a}$ & $6.13 \pm 0.61 \mathrm{a}$ \\
Hematocrit $(\%)$ & $33.90 \pm 1.00 \mathrm{a}$ & $34.70 \pm 1.25 \mathrm{a}$ \\
Leukocyte $\left(\times 10^{5} \mathrm{sel} / \mathrm{mm}^{3}\right)$ & $1.20 \pm 0.14 \mathrm{a}$ & $1.65 \pm 0.07 \mathrm{~b}$ \\
Phagocytic activity $(\%)$ & $22.46 \pm 0.79 \mathrm{a}$ & $38.65 \pm 3.62 \mathrm{~b}$ \\
Lysozyme activity $($ units $/ \mathrm{mL})$ & $19.50 \pm 3.49 \mathrm{a}$ & $43.33 \pm 3.39 \mathrm{~b}$ \\
Antibody level $(\mathrm{OD}: \lambda=450)$ & $0.57 \pm 0.01 \mathrm{a}$ & $0.79 \pm 0.13 \mathrm{~b}$ \\
\hline
\end{tabular}

Note: Different letters behind the value of the standard deviation on the same line indicates the differences between treatments $(\mathrm{P}<0.05)$.

Table 2. Lysozyme activity of egg and fry tilapia fish at the age of 5, 10, 15 days

\begin{tabular}{ccc}
\hline Parameters & Control (units/mL) & Vaccinated (units/mL) \\
\hline Egg & $19.72 \pm 1.83 \mathrm{a}$ & $33.11 \pm 2.51 \mathrm{~b}$ \\
Fry of 5 days & $12.66 \pm 2.40 \mathrm{a}$ & $20.88 \pm 3.29 \mathrm{~b}$ \\
Fry of 10 days & $12.66 \pm 2.40 \mathrm{a}$ & $20.88 \pm 3.29 \mathrm{~b}$ \\
Fry of 15 days & $2.44 \pm 0.31 \mathrm{a}$ & $24.89 \pm 3.36 \mathrm{~b}$ \\
\hline
\end{tabular}

Note: Different letters behind the value of the standard deviation on the same line indicates the differences between treatments $(\mathrm{P}<0.05)$.

Table 3. Antibody level of eggs and fry tilapia fish at the age of 5, 10, and 15 days

\begin{tabular}{ccc}
\hline Parameters & Control (OD) & Vaccinated (OD) \\
\hline Egg & $0.28 \pm 0.00 \mathrm{a}$ & $0.58 \pm 0.02 \mathrm{~b}$ \\
Fry of 5 days & $0.31 \pm 0.01 \mathrm{a}$ & $0.56 \pm 0.01 \mathrm{~b}$ \\
Fry of 10 days & $0.31 \pm 0.02 \mathrm{a}$ & $0.46 \pm 0.04 \mathrm{~b}$ \\
Fry of 15 days & $0.31 \pm 0.02 \mathrm{a}$ & $0.42 \pm 0.02 \mathrm{~b}$ \\
\hline
\end{tabular}

Note: Different letters behind the value of the standard deviation on the same line indicates the differences between treatments $(\mathrm{P}<0.05)$.

Table 4. The mortality rate (MR) and relative percent survival (RPS) of fry

\begin{tabular}{cccc}
\hline Challenge test in fry fish (days) & Treatments & MR $(\%)$ & RPS $(\%)$ \\
\hline \multirow{2}{*}{5} & Control & $76.67 \pm 5.77 \mathrm{a}$ & 78.26 \\
& Vaccinated & $16.67 \pm 2.89 \mathrm{~b}$ & 70.59 \\
\multirow{2}{*}{10} & Control & $56.67 \pm 7.64 \mathrm{a}$ & 65.52 \\
& Vaccinated & $16.67 \pm 5.77 \mathrm{~b}$ & 71.46 \\
\hline
\end{tabular}

Note: Different letters behind the value of the standard deviation on the same line indicates the differences between treatments $(\mathrm{P}<0.05)$. 
The examination of fish health status can be known from fish blood (Akinrotimi et al., 2012; Sayed \& Moneeb, 2015). The parameters that are non-specific immune response include erythrocytes cells, leukocytes cells, hemoglobin level, hematocrit level, phagocytic activity, and lysozyme activity. Whereas the parameter that is specific immune response includes an antibody (Uribe et al., 2011). The observation on broodstock hematology carried out two weeks after a vaccination. The parameters of total erythrocytes, hemoglobin level, and hematocrit level were unrelated to the immune system directly and showed not significantly different result $(\mathrm{P}>0.05)$ between treatments (Table 1). This is showed that vaccination had no effect on the total erythrocytes, hemoglobin level, and hematocrit level. Parameters that are related to the immune system directly is the total leukocyte, phagocytic activity, lysozyme activity, and antibody level.

Hematologic parameter which is a non-specific immune response include total leukocytes. Total leukocytes in vaccinated broodstock experienced a significantly increase $(\mathrm{P}<0.05)$ compared to the control treatment. This indicates that a response defense in vaccinated broodstock can increase the total leukocytes. According to Purwanti et al. (2014), the increase of total leukocytes showed a response against the foreign substances that can boost the formation of antibodies in fish. Other parameters related to the total leukocyte immune system is phagocytic activity. The phagocytic activity in vaccinated broodstock occurred a significantly increase $(\mathrm{P}<0.05)$ compared to the control treatment. This is showed that broodstock vaccination is able to increase an immune system against pathogens. Sugiani et al. (2012) and Hardi et al. (2013) proved the increasing of leukocytes after vaccination conjunction with the increase of phagocytosis activity.

Another parameter related to the immune system is the activity of lysozyme. In this study, lysozyme activity in vaccinated broodstock was higher $(\mathrm{P}<0.05)$ than the control treatment. This indicates the reaction of immune response system in vaccinated broodstock to an increase of lysozyme activity. The broodstock antibody level data obtained from this study showed significantly different results $(\mathrm{P}<0.05)$ between treatments. It is showed that vaccination can increase the antibody level in broodstock fish. Lysozyme contained muramidase enzyme that can ruin into $\mathrm{N}$-acetylglucosamine acid with $\mathrm{N}$-acetylmuramic in the cell walls of Gram-positive bacteria (Marsh
\& Rice, 2010). In the early stages, lysozyme is one of the most important proteins involved in non-specific defense (Wang \& Zhang, 2010).

The activity of lysozyme in egg in this study showed significantly different results $(\mathrm{P}<0.05)$ between treatments. It showed that the egg contains lysozyme. Lysozyme activity in fry fish at the age of 5,10, and 15 days showed significantly different results too $(\mathrm{P}<0.05)$ between treatments (Table 2). The lysozyme activity in fry fish at the age of 10 days was higher than the 5 days old and 10 days old. Lysozyme appeared at the beginning stage of the development in fish (Magnadottir, 2006). Lysozyme is a protein that involved in the nonspecific defense of fish (Wang \& Zhang, 2010). The high lysozyme level in egg plays a role in preventing pathogens vertical transfer (Swain \& Nayak, 2009).

A parameter that related to the immune system directly and as the main parameter in a specific immune response is an antibody. Antibody level in broodstock fish, egg, and fry fish in this study showed significantly different results $(\mathrm{P}<0.05)$ between treatments. It assumed because of the existence of a real immunity transfer from the broodstock to its egg. Swain et al. (2006) reported that the antibody can also be transferred from the broodstock to its egg through the formation of egg yolk. The data of antibody level in fry fish of this study was in fry fish at the age of 10 days and declined the next day (Table 3). Zhang et al. (2013) explained that the specific antibody transferred through the mother will metabolize together naturally with the egg yolk. Hanif et al. (2004) proved that the fry from the vaccinated sea bream Sparus auratus broodstock has decreased gradually until the end of the observation in 14 days after the eggs hatch. But the overall value of antibody level in fry fish showed significantly different results $(\mathrm{P}<0.05)$ between treatments.

An effectiveness of vaccinated broodstock in protecting their fry can be found by doing a challenge test in fry fish against pathogenic agents. Challenge test in fry fish was done by immersion method with the bacterial concentration that used was $10^{7} \mathrm{CFU} / \mathrm{mL}$. The mortality rate of fry fish after the challenge test through vaccination treatments showed significantly different results $(\mathrm{P}<0.05)$ compared to the control treatment (Table 4). Mortality data in fry fish at the age of 5, 10, and 15 days in vaccine treatment was smaller than the control treatment. The average of mortality rate in control was 48.33 to $76.67 \%$ larger than mortality rate in vaccinated fry was $16.67 \%$. This suggests 
that specific antibody play an important role in fish protection against pathogenic infection. Maternal antibody from the broodstock fish can reduce the risk of mortality rate during the development of fry fish (Grindstaff, 2008).

The low mortality rate and high relative percent survival in vaccination treatment are generally caused due to the formation of the specific immune response that followed by an increase of nonspecific immune system. This showed that vaccination in broodstock fish can reduce the mortality rate in their fry. According to the research results of Sukenda et al. (2017), administering the whole cell vaccine is able to reduce the mortality rate in fry fish that caused by A. hydrophila. Relative percent survival (RPS) of fry fish after challenge test showed between 65.22 to $78.26 \%$ (Table 4 ). The RPS data suggested the effectiveness of vaccination. The highest relative percent survival data presented in 5 days old of fry fish $(78.26 \%)$, compared to 10 days old $(70.59 \%$ ) and 15 days old (65.52\%). Some previous study showed that the increase of antibody in fish involved to the survival rate fry fish (Sumiati et al., 2015; Nisaa et al., 2016; Nisaa et al., 2017).

\section{CONCLUSION}

Vaccination in tilapia broodstock is effective to fix the specific and non-specific immunity and protects their fry from A. hydrophila infection through maternal immunity. Maternal immunity is characterized by the increase of lysozyme activity and antibody level in egg and fry fish. The fry fish that come from vaccinated broodstock is able to provide a protection from pathogenic infection of A. hydrophila with the relative percent survival value at the age of 5,10 , and 15 days after hatch are $78.26 \%, 70.59 \%$, and $65.52 \%$.

\section{REFERENCES}

Akinrotimi OA, Agokei EO, Aranyo AA. 2012. Changes in blood parameters of tilapia guineensis exposed to different salinity levels. Journal of Environmental Engineering and Technology 1: 4-12.

Dehghani S, Akhlaghi M, Dehghani M. 2012. Efficacy of formalin-killed, heat-killed and lipopolysaccharide vaccines against motile aeromonads infection in rainbow trout Oncorhynchus mykiss. Global Veterinaria 9: 409-415.

Fernandez JB, Yambot AV, Almeria O. 2014.
Vaccination of Nile tilapia Oreochromis niloticus using lipopolysaccharide (LPS) prepared from Aeromonas hydrophila. International Journal of Fauna and Biological Studies 1: 1-3.

Fu GH, Liu F, Xia JH, Yue GH. 2014. The $\angle B P$ gene and its association with resistance to Aeromonas hydrophila in tilapia. International Journal of Molecular Sciences 15: 22028-22041.

Gudding R, Willem B, Muiswinkel V. 2013. A history of fish vaccination science-based disease prevention in aquaculture. Fish and Shellfish Immunology 30: 1-6.

Grindstaff JL. 2008. Maternal antibodies reduce costs of an immune response during development. Journal of Experimental Biology 211: 654-660.

Hanif A, Bakopoulos V, Leonardos I, Dimitriadis GJ. 2005. The effect of sea bream Sparus aurata broodstock and larval vaccination on the susceptibility by Photobacterium damsela subsp. piscicida and on the humoral immune parameters. Fish and Shellfish Immunology 19: 345-361.

HardiEH, Sukenda, Harris E, Lusiastuti AM. 2013. Potential vaccine candidate of Streptococcus agalactiae for prevent strepcococosis on Nile tilapia Oreochromis niloticus. Jurnal Veteriner 14: 408-416.

Hardi EH, Pebrianto CA, Hidayanti T, Handayani RT. 2014. Phatogenicity of Aeromonas hydrophila via some port entryin cultured Nile tilapia Oreochromis niloticus from Loa Kulu Kutai Kartanegara Kalimantan Timur. Jurnal Kedokteran Hewan 8: 130-133.

[KKP] Kementerian Kelautan dan Perikanan. 2016. Laporan kinerja (LKj) Direktorat Jenderal Perikanan Budidaya tahun 2015. Jakarta (ID): KKP

Magnadottir B. 2006. Innate immunity of fish: overview. Fish and Shellfish Immunology 20: 137-151.

Marsh MB, Rice CD. 2010. Development, characterization, and technical applications of a fish lysozyme-specific monoclonal antibody (mAb M24-2). Comparative Immunology, Microbiology and Infectious Diseases 33: $15-23$.

Mingming H, Fu Hong D, Zhen M, Jilin L. 2014. The effect of vaccinating turbot broodstocks on the maternal immunity transfer to offspring immunity. Fish and Shellfish Immunology 39: 118-124. 
Nisaa K, Sukenda, Junior MZ, Lusiastuti AM, Nuryati S. 2016. Resistance of tilapia Oreochrimis niloticus fry vaccinated at different gonadal developmental stages toward Streptococcus agalactiae infection. Jurnal Veteriner 3: 355-364.

Nisaa K, Sukenda, Zairin M, Nuryati S, Lusiastuti AM. 2017. Fry tilapia Oreochromis niloticus antibody improvement against Streptococcus agalactiae through broodstock vaccination. Pakistan Journal of Biotechnology 14: 9-16.

Purwanti CS, Suminto, Sudaryono A. 2014. The description of blood profile catfish Clarias gariepinus that is fed with a combination of artificial feed and earthworm Lumbricus rubellus. Journal of Aquaculture Management and Technology 3: 53-60.

Sayed AEH, Moneeb RH. 2015. Hematological and biochemical characters of monosex tilapia Oreochromis niloticus Linnaeus 1758 cultivated using methyltestosterone. The Journal of Basic and Applied Zoology 72: 36-42.

SugianiD, Sukenda, HarrisE,Lusiastuti AM. 2012. Haematology responses and histopathology of tilapia Oreochromis niloticus to co-infection Streptococcus agalactiae and Aeromonas hydrophila. Jurnal Riset Akuakultur 7: 85-91.

Sukenda, Pratiwi KA, Rahman, Hidayatullah D. 2017. Efficacy of whole cell vaccine Aeromonas hydrophila on catfish broodstock and it's offspring resistance againt motile aeromonad septicemia (MAS). Jurnal Akuakultur Indonesia 16: 92-100.

Sumiati T, Sukenda, Nuryati S, Lusiastuti AM. 2015. Development of ELISA method to detect specific immune response in Nile tilapia $O$. niloticus vaccinated against $A$. hydrophila and S. agalactiae. Jurnal Riset Akuakultur 10: 243-250.

Swain P, Dash S, Bal J, Routray P, Sahoo PK, Sahoo SK, Saurabh S, Gupta SD, Meher PK.
2006. Passive transfer of maternal antibodies and their existence in eggs, larvae and fry of Indian major carp, Labeo rohita. Fish and Shellfish Immunology 20: 519-527.

Swain P, Nayak S.K. 2009. Role of maternally derived immunity in fish. Fish and Shellfish Immunology 27: 89-99.

Tantu W, Tumbol RA, Longdong SNJ. 2013. Deteksi keberadaan bakteri Aeromonas sp. pada ikan nila yang dibudidayakan di karamba jaring apung Danau Tondano. Jurnal Budidaya Perairan 1: 74-80.

Uribe C, Folch H, Enriquez R, Moran G. 2011. Innate and adaptive immunity in teleost fish: a review. Veterinarni Medicina 56: 486-503.

Wang H, Ji D, Shao J, Zhang S. 2009. Maternal transfer and protective role of antibodies in zebrafish Danio rerio. Molecular Immunology 51: 332-336.

Wang H, Ji D, Shao J, Zhang S. 2012. Maternal transfer and protective role of antibodies in zebrafish Danio rerio. Molecular Immunology 51: 332-336.

Wang SH, Wang Y, Ma J, Ding YC, Zhang SC. 2011. Phosvitin plays a critical role in the immunity of zebrafish embryos via acting as a pattern recognition receptor and an antimicrobial effector. Journal of Biological Chemistry 286: 22653-22664.

Wang Z, Zhang C. 2010. The role of lysozyme and complement in the antibacterial activity of zebrafish Danio rerio egg cytosol. Fish and Shellfish Immunology 29: 773-77.

Yi T, Li WY, Liu L, Xiao XX, Li AX. 2014. Protection of Nile tilapia Oreochromis niloticus L. against Streptococcus agalactiae following immunization with recombinant FbsA and $\alpha$-enolase. Aquaculture 428-429: 35-40.

Zhang S, Wang Z, Wang H. 2013. Maternal immunity in fish. Developmental and Comparative Immunology 39: 72-78. 